\section{Components of Strength of the Auburn Horticulture Undergraduate Program}

\author{
Jeff L. Sibley, ${ }^{1}$ \\ D. Joseph Eakes, ${ }^{2}$ \\ J. David Williams, ${ }^{1}$ and \\ Harry G. Ponder ${ }^{2}$
}

\begin{abstract}
AdDitional INDEX wORDs. undergraduate education, students, horticultural instruction, teaching methods, laboratory exercises
\end{abstract}

Summary. The unprecedented, yet sustained, growth of undergraduate enrollment in the Department of Horticulture at Auburn University can be attributed to many factors, including an increased industry demand for horticulture graduates nationwide. Perhaps the basis of some of Auburn's growth, while appearing to be unique, may be of value in other programs. This paper chronicles the growth of the Auburn Department of Horticulture undergraduate program and highlights some of the traditional teaching methods employed within the department as well as some unique methods that contribute to the program. The paper offers ideas and practices that may be beneficial to other horticulture programs and may encourage teaching faculty at other institutions to publish similar departmental profiles that may prove beneficial to colleagues.

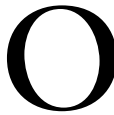
ver the past century as the southern United States has become more urbanized and the number of traditional farms and farmers has substantially declined (USDA, 2000), involvement in horticulture has shown a marked and consistent increase. Growth of the

Department of Horticulture, 101 Funchess Hall, Au burn University, AL 36849.

${ }^{1}$ Associate professor.

${ }^{2}$ Professor.
Auburn University Department of Horticulture is one expression of this new and sustained interest, with increased enrollment each fall for 16 of the last 17 years (Fig. 1). This growth accounts for a $330 \%$ increase in student numbers since 1985 and the largest enrollment in the 126 year history of this department, placing Auburn University's Department of Horticulture among the larger undergraduate horticulture programs in the United States. In 1985, the Department of Horticulture was represented by $7 \%$ of the students in the College of Agriculture, whereas in 2001 it accounted for $30 \%$ of those students. While some departments within our college have declined in student numbers (Entomology, Plant Pathology, Agricultural and Biosystems Engineering) and others have maintained a steady but flat enrollment (Agricultural Economics and Rural Sociology, Agronomy and Soils), it is clear that enrollment in the Department of Horticulture has been growing at a disproportionately faster rate compared to other departments in the college. When the department was evaluated over the last five decades it sented the highest average enrollment of any decade at 169 students, or $23 \%$ of the students in the College of Agriculture (Fig. 2). Auburn's Department of Horticulture has 16 permanent faculty members, 30 graduate students in $\mathrm{MS}$ or $\mathrm{PhD}$ programs, and 240 underbecame apparent that the 1990s repre-

graduate students pursuing 4-year BS degrees available in three areas: Fruit and Vegetable Production (20 students), Landscape Horticulture (165 students), and Ornamental Production (55 students). These numbers do not reflect turfgrass (housed in the Department of Agronomy and Soils) or Landscape Architecture (housed in the College of Architecture and Building Science) students. The undergraduate ornamental horticulture program at Auburn was rated seventh in the nation in 1998 (Gourman, 1998).

For more than 17 consecutive years, every Auburn horticulture graduate, at both the undergraduate and graduate level, desiring to have employment in the horticulture arena has been placed in a career-track position upon or before graduation. The unprecedented growth of the department is attributed to many factors that, based on our observations, would include an increased industry demand for horticulture graduates nationwide. Over 50 horticultural companies representing 40 different states come to campus annually to interview graduating students as prospective employees and other students as potential interns. Faculty teaching evaluations consistently place the horticulture faculty above average within the College of Agriculture (W.E. Hardy, Jr., personal communication). In addition to a reputation for teaching excellence, two important components of undergradu-

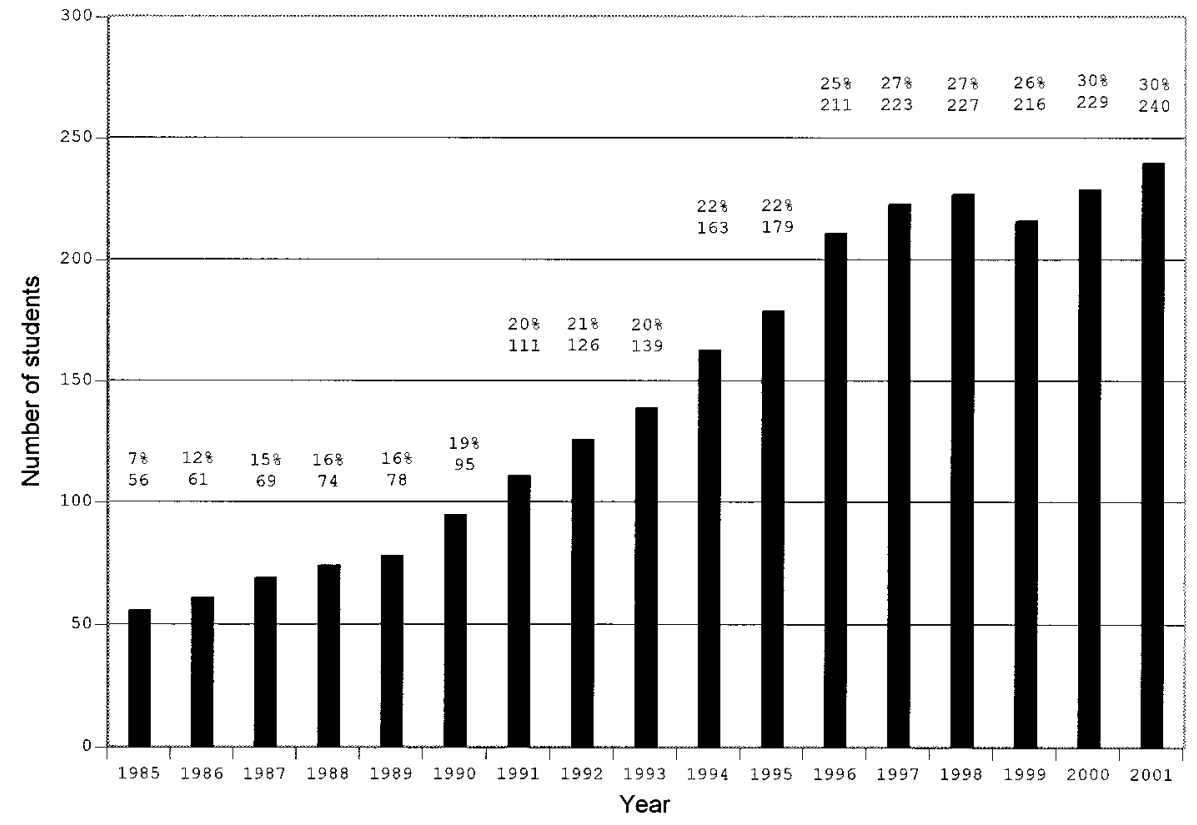

Fig. 1. Number and percentage of horticulture students in the total undergraduate population in the College of Agriculture, Auburn University, 1985-2001. 
ate education that attract prospective employers seeking Auburn University horticulture graduates are an educational curriculum focused on the needs of the industry and job experience (D. Elkins, personal communication).

\section{Traditional departmental approaches}

A viable degree track program is offered during the summer term with the following courses taught: Organic Gardening(HORT 2040), Landscape Gardening (HORT 2210), Plant Propagation (HORT 2240), Interior Plants and Flower Arranging (HORT 2250), Herbaceous Plant Materials (HORT 4100), Retail Garden Center Management (HORT 4150), Intermediate Landscape Design (HORT 4270), Advanced Growth and Development of Horticultural Plants (HORT 7040) (even years), Tree Fruit Culture (HORT 4100/7100) (odd years), and Nutritional Requirements of Horticultural Plants (HORT 7050) (odd years). These courses are not rotated but are taught every summer at capacity enrollment (capacity based on physical space, typically from 40 to 60 students per 3- or 4-semester-hour course with two laboratory sections) with most classes having waiting lists. Summer courses enable many students to graduate on time as well as obtain some of the more valuable spring internships (allowing a student to experience the industry at its peak), while being assured that graduation will not be delayed.

Summer teaching has increased faculty teaching loads; however, all faculty in our department are on 12month appointments with summer loads considered a part of individual assignments. To emphasize the importance of undergraduate teaching at Auburn University and to maximize use of space throughout the year, the President and the Board of Trustees have provided additional departmental support beyond the normal fiscal year budget based on credit hours generated in the summer term. In recent years this extra revenue has provided the support for two post-MS teaching associates in the department.

The department uses teaching gardens on campus, a departmental greenhouse complex with adjacent developed acreage, and a departmentally-managed residential landscape property in a number of classes to teach landscape construction (paver installation, concrete installation, etc.), landscape management (pruning, plant installation, problem solving etc.), and garden design.

Field trips take students to business locations. Utilizing business professionals as classroom speakers brings the business to the student and provides greater exposure to a diverse group of enterprises beyond the range of field trips. Guest speakers are generally selected from firms that regularly hire our students and most of the speakers are former students. Prior to arrival on campus, speakers and instructors discuss the areas to be addressed in class so as to avoid conflicts of practices and professional philosophies.

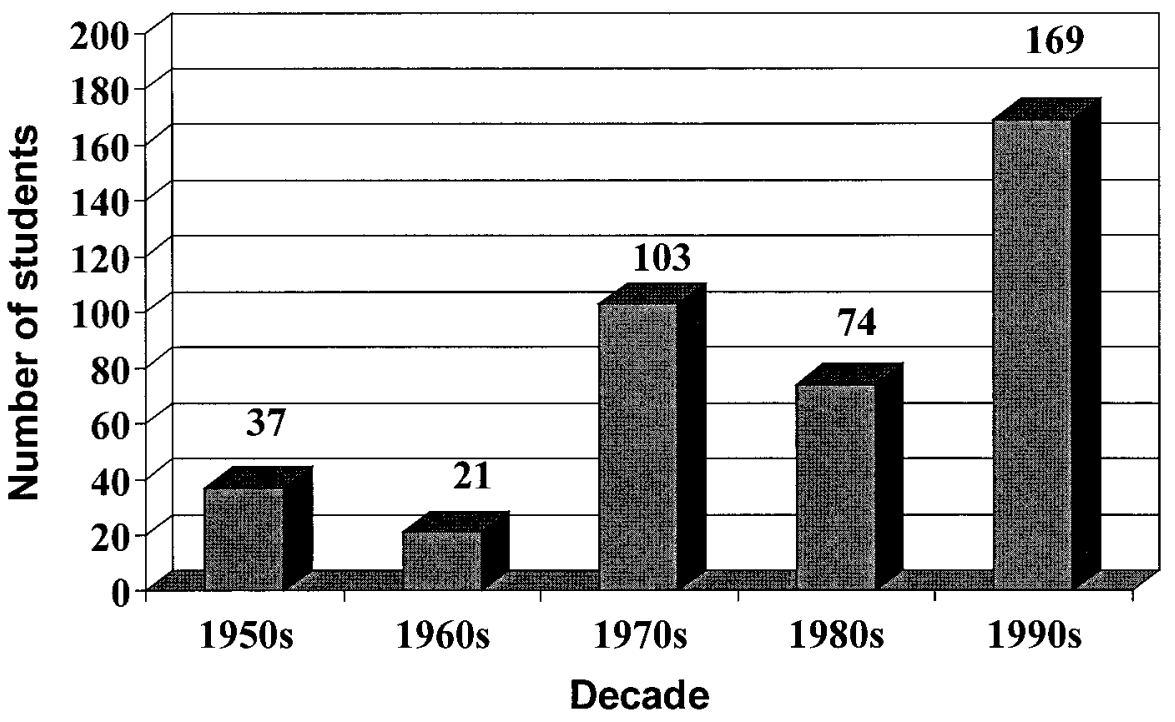

Fig. 2. Enrollment trend for the Department of Horticulture at Auburn University averaged over each of the past 5 decades.

\section{Recent improvements or novel approaches in selected classes}

Plant propagation (hort 2240). With increased interest in turfrelated employment, a section on stand establishment of turfgrass from seed and/or vegetative means has been incorporated into the Plant Propagation course. This section includes some of the unique equipment used in this specialized form of vegetative propagation. Unique assignments in this course include: An out-of-laboratory seed collection by each student, including appropriate preparation of collected seed for storage, and a written description of specifications appropriate to the seed collected (Wehner, 1993). A rental truck is used to teach hands-on techniques of ladder stacking or shelving plants for shipping. Other practical problem/skill/ trade related exercises included in Plant Propagation are assisting greenhouse personnel with covering a poly hoophouse, and demonstration of innovative equipment retrofits and adaptations used in the industry.

Plant Propagation laboratories have been conducted in a variety of styles during recent years. According to Garrett (1993), practical experience in plant propagation is a great benefit to the student both in and out of school. Traditional laboratories with 15 to 22 students per instructor are common and constitute the majority of the laboratories throughout the term. Although more time-consuming from the instructors' standpoint, students seem to prefer the open laboratory approach where they are free to come and go during the assigned laboratory day for certain blocks of time, as long as the number present does not exceed a predetermined instructorstudent threshold. This approach allows more individual one-on-one attention and is particularly beneficial in budding and grafting laboratories and tissue culture laboratories (that are conducted from kit-ready exercises from Carolina Biological Supply; Burlington, N.C.; www.carolina.com). An in-between approach is dividing a 15 to 22 student laboratory up into 3 to 4 subgroups with the instructor rotating from group-to-group within the assigned laboratory period.

Retail garden Center manageMENT (HORT 4150). In a review of 
curricula in current catalogs from across the southeastern U.S., our department is one of three departments of horticulture offering a specific course in Retail Garden Center Management, the others being the University of Florida and North Carolina State University. Although taught in the summer, the course has been filled beyond capacity each year. The course provides management type instruction in sales and service, garden center design and layout, site selection using demographic profiles, personnel selection and supervision, product mix and inventory control. Employers have recognized the value of such a course based on the demand for students who have taken this course (W.P. Juers, personal communication).

LANDSCAPE Design. Typically students in Landscape Gardening (HORT 2210 ) (taught three times per year on the quarter system; two times per year upon semester conversion in Fall 2000) will concentrate on one residential design per term. Landscape design is taught through progressive plan development in Intermediate Landscape Design (HORT 4270) (taught twice per year) using the following steps: 1 ) a kit-ready plan, 2) front yard only, 3 ) front yard and back yard, 4) small commercial, and 5) a comprehensive residential design as a final project. Advanced Landscape Design (HORT 4280) (taught once per year) students typically prepare one design per week, typically residential in nature. Local homeowner landscapes are carefully selected several months in advance for the class design projects in most cases. With design classes taught throughout the year, maintaining a waiting list of suitable projects has occasionally been difficult. Client interviews are conducted on site for each project. Design presentations are staged with the instructor and graduate teaching assistant initially, then with a client on the final project. About $15 \%$ to $20 \%$ of students in the Landscape Design option use Advanced Landscape Design as a professional elective (a category of electives related specifically to degree track). Independent Studies in Landscape Design (HORT 4930) problems are addressed one-on-one following the Intermediate or Advanced Landscape Design classes for more intense instruction and training.

Herbaceous plant materials (HORT 4100). Student projects are used as a hands-on means of applying lectures to the field. Throughout the term, each student develops a flowering sequence calendar as a component of plant materials laboratories. Each student designs, plants and maintains a container garden for placement in a campus courtyard. Evaluations are based on appropriate plant selection, creativity and neatness, installation as shown in the design, and quality of maintenance. Beds around campus buildings used in the teaching of herbaceous plant materials are installed by groups of students. Each group contracts to design, install, and maintain assigned areas with the campus Grounds Division under the supervision and evaluation of the course instructor. All equipment, amendments, transportation, and plant materials are provided as needed. Evaluation is based on design, installation, participation, maintenance and a written report based on a daily log of group activities.

HORTICULTURE INTERNSHIP (HORT 3920). Since the beginning of a structured internship program in 1981, scheduling creative and traditional internships is an ongoing quest for several of our faculty. Our department coordinates the largest single-major internship program on Auburn's campus, placing more than 75 students in domestic and international internships annually. The sooner a student is plugged-in to our overall industry, the more likely that student is to finish his/her degree and go on to occupational success. Some of the traditional internships offer experience in container production, landscape design and installation, and temporary sales positions with allied agrichemical or supply companies. Other internships such as interpretive or nature lore positions at summer camps or public gardens, and positions in large grocery stores are more indirectly connected to horticulture. One former student capitalized on such an opportunity and now manages a very successful floral shop in a large store. Grocery stores have long provided a good source of employees - employees trained in computer tracking of inventory and point of sale computer (register) work, inventory management, customer service and satisfaction, profit margins, warehousing and shipping, as well as developing an understanding of the nature of managing perishable goods (J. Wilson, personal communication).
LANDSCAPE CONSTRUCTION (HORT 3280). Afteryears of dormancy, Landscape Construction was resurrected in 1997. This was in response to the stated need by frequent industry recruiters for more hands-on learning in the area of landscape construction to support preparation of students for this aspect of the landscape industry. The course emphasizes the principles and application of basic aspects of landscape construction and is complemented by field trips.

Using muddy points, similar to those outlined by Preece (1993) and Mosteller (1989), as anonymous feedback tools during the instruction period have been extremely effective. Students are periodically given the opportunity to write down the muddiest (most confusing) aspects of the course as a means of requesting clarification in course material. The general approach prior to the muddy points idea was to wait until the traditional teacher evaluations came back some months after the class was completed with the determination to "do better next time" or "do it again - if I can just remember." This traditional way did not allow for midstream adjustments, or a true concern for total student comprehension. The muddy points idea remedied this, was well received by the students, encouraged less gregarious students to get involved in learning, and subsequently led to improvements in the administration-mandated teacher evaluations.

How long our current growth curve will continue to show an increase remains to be seen. With prospects of new faculty positions limited due to funding constraints, research-instruction-extension appointments have become a little blurred with existing faculty teaching most classes several times a year with multiple sections. Additionally, a significant number of faculty with no official instructional assignment teach many of the specialized courses, particularly in the areas of fruit, vegetable, and nut production. In Alabama, viability standards for academic programs and departmental funding are governed by the Alabama Commission on Higher Education. Departments face extinction if their student numbers fall below mandated levels. We are working in a time when steady or increasing student numbers are critical to funding and existence. Currently, Auburn's administration 
prides itself on undergraduate instruction while realizing there is a price to be paid at the operational level. While our faculty have generally been flexible and adaptable to change, individuals handle teaching pressures differently, with most faculty within the department shifting their focus away from development of extramural funding as teaching loads have increased. Under the current structure, our department could realize continued undergraduate enrollment in the fruit and vegetable area. However, physical constraints and limited personnel appear to limit realization of some potential growth in other areas. Furthermore, the long-term impact of a transition for the Auburn University system from a quarter to a semester calendar in the fall of 2000 is uncertain. While these are problems we must meet, development and implementation of creative teaching methods and techniques will continue to be necessary to maintain the quantity and quality of graduates needed in the horticulture industry.

\section{Literature cited}

Garrett, F.W. 1993. Propagation in school and out-myth and reality. Proc. Intl. Plant Prop. Soc. 43:413-417.

Gourman, J. 1998. The Gourman report. A rating of undergraduate programs in American and international universities. 10th ed. Random House, New York. p. 285.

Mosteller, F. 1989. The "muddiest point in lecture" as a feedback device. On teaching and learning. J. Harvard Danforth Ctr. 3:10-21.

Preece, J.E. 1993. Nongraded assessment of student expectations and understanding in horticulture classes. HortTechnology 3:354-356.

U.S. Department of Agriculture. 2000. 1999 Agricultural statistics. USDA, Natl. Agr. Stat. Serv. 2 Aug. 2000. <http://www.usda.gov/ nass/pubs/agstats.htm>.

Wehner, D.J. 1993. Writing assignments for horticulture courses. HortTechnology 3:45659. 